\title{
Radio wars in PNG: NauFM's tough struggle
}

WHILE NauFM goes from strength-to-strength, its established rival Radio Kalang has been on the verge of collapse. However, clouding NauFM's silver lining are serious questions about the quality and style of its news and information programs.

\section{By RAPHAEL SEMEL}

NAUFM, the digital broadcaster that has had a meteoric rise in Papua New Guinea, is dominating the commercial radio industry and may soon be the only entertainer. Why? The rival entertainer, KalangFM, is in a financial crisis and may go off air.

Glancing at his computer with smiles, NauFM general manager Mark Rogers says his station has struggled through a rough journey. But it has now established its market and audience.

'It has established the programs and activities which suit its market and listenership,' Rogers says.

A listenership survey conducted last year by First Market Search on behalf of NauFM showed the group ranging from 15 to 40 year olds want the new station. The finding has delighted NauFM as the majority of the country's population is in that age group. Before NauFM was established, Rogers conducted research for six months in 1994 and found a great potential market for commercial radio. The research encouraged the start of NauFM.

A developing country like PNG needs an electronic medium wave means of communication, especially radio, because:

$\square$ Newspapers cannot reach remote areas.

$\square$ Electricity is unavailable in villages for television.

$\square$ News and other programs broadcasts are informative to the people.

The new computerised station reaches an audience throughout PNG and the South Pacific. Although NauFM is 80 per cent PNG-owned, the minority 20 per 
cent is held by Fiji broadcaster Communications Fiji Ltd which has the management contract.

Training: Rogers says NauFM staff are trained to use the advanced facilities in the studio. They have a training program to allow them to go to US, Australia, Fiji or Japan for a course or a workshop. Deputy news director Robyn Sela recently toured the US to observe different media organisations, their facilities and how they operate.

'NauFM staff try to get a balanced news to relay to the people. The broadcaster plays about 25 to 30 per cent local music every day,' Rogers says.

Robyn Sela says NauFM is a music station that tries to meet the expectations of the young people of today. The station has a lot of gaps for other programs and staff have made recommendations to the general manager for new programs like current affairs, health, talk back shows and others. However, Rogers is satisfied with the present ones so none may be introduced.

The staff have widened the sales and advertising avenues, attracting many clients to promote their products on NauFM.

'I am glad to see good competition among Kalang, Karai, Kundu services and NauFM. This will force the staff to be on their toes to produce the best news and programs," says Sela.

NauFM is one of the few private FM radio stations in the South Pacific. Now Fiji has fallen in line with NauFM, also using the digital system for broadcasting.

News director Patrick Patu does not have a professional journalism qualification, and he is criticised for this by some Port Moresby media commentators. But as an experienced broadcaster, he has a specialised talent in sport so he produces good sports news. Other news is collected from other provinces by stringers.

'A plan is in the pipeline to establish offices in various main centers so they would enable NauFM to receive and disseminate more information to the local people,' says Sela.

Dream work: A former news director, Weni Singarok, who now works for the $A B C$, says: 'The facilities in the new station still ring in my mind, bringing back my dream to work in such a station.' However, she finds it 'unfortunate' for NauFM that it does not have an experienced journalist 'checking the news content' of reporters. Singarok, wife of the military commander, BrigadierGeneral Jerry Singarok, believes it would be better for NauFM to have a news director with a journalism background to deal with journalism issues, such as defamation, talance, ethics and professionalism.

Broadcast journalism lecturer of the University of PNG's South Pacific 


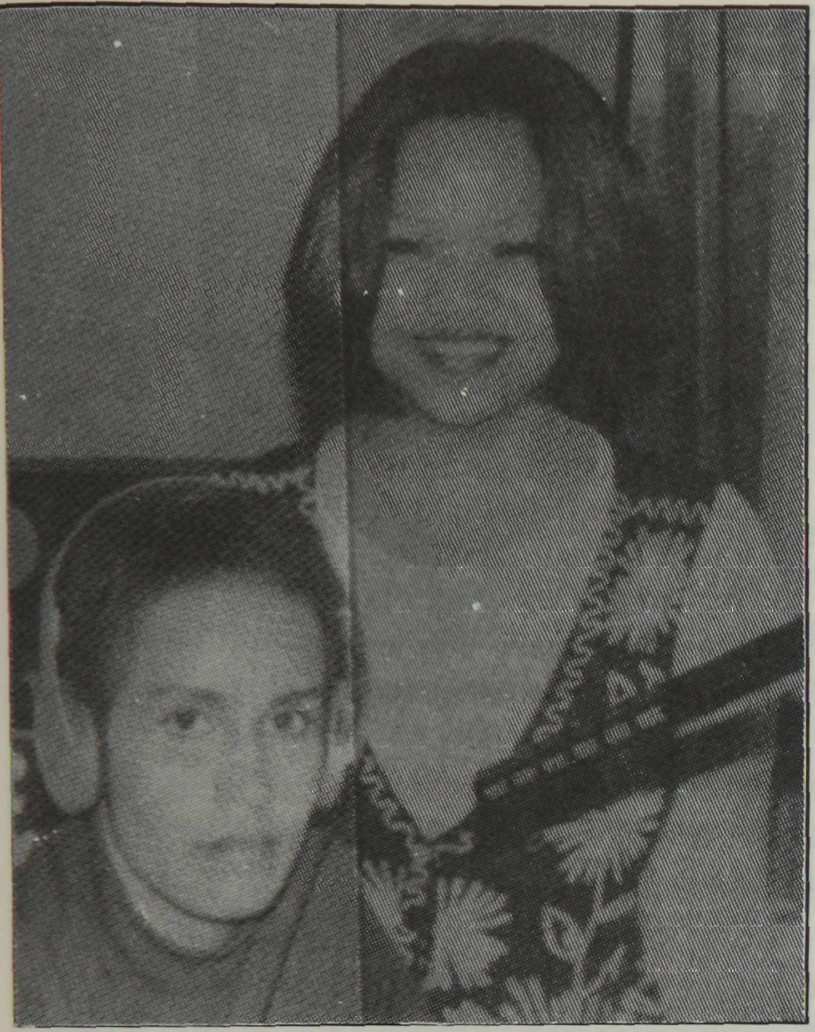

DJs Eli Webb (left) and Rhoda Mojica.
Centre for Communication and Information in Development, Sorariba Nash, believes NauFM is meeting its capacity and standard of producing news, advertisements and music. He says NauFM has achieved its goal as a commercial station. The well-equipped newsroom has the latest technology. Computers make programs, slot them into segments and time them accurately so the system flows smoothly. The newsroom also monitors world news from television and radio stations.

Shallow: 'Radio stations should have the kind of equipment like NauFM, so

they can reach different locations in spite of the terrain, mountains or sea,' says Nash. Journalism graduates of UPNG now working at NauFM have a great opportunity to edit and produce news due to the new facilities.

But Nash says: 'The news content is so shallow and some news is being extracted from newspapers or other radio stations and television.' Although based in the nation's capital, NauFM still lacks coverage of some significant events happening here in the city.

Ian Boden, a commentator and broadcaster now with The National, says NauFM does not have special programs such as current affairs, health and others because it has different objectives. 'It is a commercial station fulfilling its duty accurately by producing "home grown” advertisements, says Boden.

The PNG Media Council chairperson, Anna Solomon, was reluctant to comment about the progress of NauFM because the council was still at an 'interim stage'. 'I only work on print media and also do not listen to NauFM so I would not make any comment about the operation and progress of the station.' she says.

Listeners interviewed gave more criticism than positive comments about NauFM. Their views were based on a comparison of programs among the radio 


\section{Why can't Kalang push ahead on its own?}

\section{COMMENT: By Sorariba Nash}

WHEN something goes wrong, attracts a lot of attention and raises concern, we're quick off the mark to ask: what happened? How did this happen to Radio Kalang and why did it happen the way it has? Most of all - who is to blame?

In Radio Kalang's case we cannot blame the government for lack of funding support. Kalang is an entirely independent business entity and should have been generating revenue with an annual expenditure budget of its own. Most importantly of all it should have survived in the business world.

One of the major objectives of establishing Radio Kalang was for it to operate as the commercial arm for the National Broadcasting Commission and help the mother station fund its operational costs. However, this has not been the case. Radio Kalang has become a liability to the NBC.Kalang would have closed without NBC backing.

Apart from allegedly owing money to business houses like MBF Finance and Chin H Min, Kalang is alleged to owe a lot of money to NBC's news service department. NBC has kindly housed the ailing business arm and given general support despite its troubled years.

Quite often, the fault lies within - even if it is really from the outside, it is wise to start from within to put the house in order. In this day of aggressive competition, the NBC should have started cleaning up from inside ages ago.

Even Kalang's top management is a shaped like a mushroom - with highly paid executives sitting on a skinny frame, struggling to uphold their fat salaries and pay for their sporty model cars which attend to more personnel task than business.

Kalang could have initiated such moves and instilled discipline as the business entity, looking for ways to reduce the salary bill. It could have taken a hard look at the word "redundancy".

NBC is still reluctant to examine this word and therefore its salary bill is absorbing most of the budget. Radio Kalang is burdened with this problem, a rub off from the mother organisation from the past.

We are aware that the MBF Finance has repossesed a fleet of cars 


\section{RADIO KALANG}

from Radio Kalang, CHM has stopped producing Kalang music cassettes, and apart from other business houses severing its business relationship with Kalang because of non payment of bills - what happens if $\mathrm{NBC}$ newsroom stops supplying news for the 'on the hour every hour' service?

For several years Kalang has enjoyed a monopoly in the radio advertising market, but failed to capitalise on its domination and make money.

What was the problem? Did they fail to create incentives? Try out new ideas? Did they run out of creativity? Lose a sense of direction or was it lack of foresight? Well, what really happened? The public deserves to know.

Even with the pressure of 'hard times', NauFM is pushing ahead on its own without support. Why can't Radio Kalang do the same?

$\square$ Sorariba Nash is broadcast journalism lecturer at the South Pacific Centre for Communication and Information in Development (SPCenCIID).

\section{journupng@pactok.peg.apc.org}

stations and an expectation that the new radio should be similar to existing stations. One listener, who did not want to be named, said: 'NauFM is so fancy in its broadcasting and its music is more for the whitemen.'

Too fast: The audience could hardly hear or comprehend what was said in the advertisements because staff working at NauFM were young and mixed-race who speak too fast, the listener added. An 18-year-old man said NauFM played only rock music.

'How about playing more local music clips?' he asked. 'Why can't NauFM produce a variety of programs which could attract and interest the listeners?'

Meanwhile, an alleged debt of K1.1 million has left the rival FM station, Radio Kalang, the commercial arm of NBC, in a precarious position over its future. At present, Kalang FM is still on air but debts could rise.

Kalang fans' confusion rankles as NauFM forges further ahead.

$\square$ Raphael Semel is a third-year journalism student and a former Independent reporter in PNG. This article was published in the 24 May 1996 issue of Uni Tavur. 